\title{
Tateando ao menos duas fronteiras de um campo para a comunicação
}

EUGÊNIO BUCCI 


\section{Resumo}

A comunicação, entendida como prática dialógica no espaço público, suscita um campo do conhecimento que ainda se encontra em formação. Há esforços plurais que apontam para a autonomia desse campo, segundo paradigmas teóricos diversos. Uma pergunta central que orienta o artigo é: de que modo conceitos e noções de outros domínios podem ganhar uma nova amplitude no campo da comunicação, que os importa, que os manda vir, lá de sua origem distante, para se prestarem a próprias indagações próprias do campo dầ comunicação?

\section{Palavras-chave}

campo da comunicação, sociologia habermasiana, teoria psicanalítica

\section{Abstract}

The communication, understood as the main practice that creates the public space, raises a field of knowledge, still in formation, which aims at understanding the practice and the communicational nature of the public space. There are plural efforts that intend to create the autonomy of this field, according to several theoretical paradigms. A central question that guides the article is: can concepts and notions of other domains win a new width in the field of the communication? In other words: can these ideas, that are strange to the field of communication in their origins, be helpful to this field when it needs to think itself?

\section{Key words}

field of communication, habermasian sociology, psychoanalytic theory 


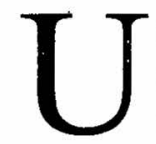

ma interrogação serviu de ponto de partida para o presente artigo ${ }^{1}$. É uma interrogação singela, que nada tem a ver com ele, o artigo. Ei-la: “Qual o lugar da televisão?”'É singela de fato, chega a ser infantil - e dela não nós ocuparemos muito. Ora, o lugar da televisão... Que tal na sala de estar? Ou na internet? Essa pergunta não importa, agora, para o que aqui se vai discutir. Por isso, aliás, ela não tem nada a ver com o propósito deste texto. O que importa é que dessa pergunta, ao longo de uma pesquisa acadêmica, surgia uma resposta que, em si, era outra pergunta. Talvez igualmente singela, para não dizer infantil. O lugar da telévisão é o campo da comunicação - e, pois bem, onde se situa o campo da comunicação?

Estruturas espaciais, tracejados geográficos, figuras geométricas móveis começaram a insurgir-se como suportes de um raciocínio precário. Estamos aqui numa fase embrionária do pensamento, quando ele se confunde com uma função de cartografia sobre o desconhecido. $O$ cirurgião que rabisca o ventre do paciente antes de ali proceder à incisão. $\mathrm{O}$ explorador do Eldorado. $\mathrm{O}$ fotógrafo que, com os próprios dedos trêmulos, toca o queixo de sua musa para elevar-lhe um pouco mais a face de modo a rebater distraidamente a luz. O político que gesticula demarcando no ar volumes intangíveis e ali confinando, no decorrer do seu discurso, as áreas distintas de seu

1. Este artigo tem como ponto de partida um antigo projeto de pesquisa, agora em fase de conclusão. Ele não se confunde com aquela pesquisa (minha tese de doutorado, cujo texto integral será apresentado em fevereiro de 2002 na Escola de Comunicações e Artes da Universidade de São Paulo e cujo tema é o estabelecimento de um método teórico para a crítica de televisão); é apenas um desdobramento lateral dessa pesquisa. A pedido dos editores desta revista, que acompanharam a evolução da tese, este artigo se apresenta com o objetivo de contribuir para o debate em torno do campo da comunicação. Trata-se de uma contribuiçãa modesta, além de sumária. Sua motivação é antes buscar pontes de diálogo com outras áreas e domínios que estabelecer cortes em relação a eles. 
governo, aqui está a Saúde, ali fica a Segurança, como o cozinheiro que diagrama a pia da cozinha para reservar o pote com cebola picada, o outro com coentro e assim por diante, antes de começar a executar a receita, e fica no interlocutor a sensação de que o político de potes invisíveis no ar, como o cozinheiro de potes concretos sobre o mármore, irá depois lançar mão dos conteúdos de um e de outros e assim irá dar sentido ao discurso que se inicia. São procedimentos táteis do pensamento - táteis concretos ou táteis abstratos. É mais por meio deles que aqui se vai falar do campo da comunicação.

Eu suponho, desde logo, que a televisão não se inscreve como ilha dentro de um campo já estabelecido. Isso por duas ordens de razões. A primeira é dada pela precariedade epistemológica de um suposto (pretendido) campo teórico da comunicação, quer dizer, essse campo não se encontra ainda estabelecido; só mais recentemente é que vem procurando instaurar-se e se fazer reconhecível. A segunda ordem de razões, tem a ver diretamente com a constatação de que, uma vez identificados os alcances da televisão como objeto, nota-se que ela mesma, televisão, estende-se para longe, avizinhando-se, aqui e ali, de objetos de ciências exteriores ao campo (em formação) da comunicação. Desse modo, seus contornos se confundem com os contornos do campo no qual ela, televisão, estaria posta.

Que campo é esse, o da comunicação? - a indagação é apenas uma outra possibilidade daquela mesma, singela, infantil, que se sublevou logo no início deste texto. E deverá contentar-se com uma resposta indicativa. O termo campo, bastante difundido a partir da obra de Pierre Bourdieu ${ }^{2}$, vem admitindo significados diversos. Não pretendo, ao menos agora, empregar o termo no sentido estrito que lhe dá Bourdieu. Por ora, ele se presta apenas a designar, provisoriamente, previamente, uma esfera prático-teórica, por certo, cujo centro de

2. Por agora, é satisfatório entender o campo como um "mundo à parte, sujeito às suas próprias leis", o que Pierre Bourdieu (1997,'p. 64) diz da literatura a partir de Flaubert e Baudelaire. Outro texto, Sobre a televisão (Rio de Janeiro: Jorge Zahar Editor, 1997) constitui, uma leiturá particularmente esclarecedora sobre a mesma noção uma vez que , aí, o autor analisa criticamente um fenômeno que não é outro senão o da absorção do campo intelectual e acadêmico pelo campo (de mercado) dos telejornais das emissoras de TV comerciais, ou seja, o fenômeno que faz com que as "leis próprias" do campo intelectual se dobram às leis do telejornalismo que produz celebridades e entretenimento. Ver ainda, do mesmo autor (1990, pp. 26, 45, 54), . Nesse miesmo livro, ver "o campo como um lugar de lutas", p. 172. Ver, também, Bourdieu, Pierre (1984). 
gravidade é um paradigma discursivo que concilia objeto método com relativa autonomia em relação ao que lhe é contígu@ ou exterior.: ${ }^{3}$ Para efeitos do que aqui se diz, um campo constitui ao mesmo tempo um espaço teórico e uma unidade autônoma seja no mundo das ciências, seja no mundo das práticas sociais. No que concerne ao campo da comunicação, ele deve ser entendido como uma esfera em fase de postulação e em busca de autonomia teórica frente às outras ciências sociais.

"Pois bem, prossigamos com aquela metáfora geográfica, ou mesmo tátil. Pode-se dizer que percorrer as fronteiras da vizinhança estabelecida pelo objeto inicial, a televisão, é explorar um território virgem; é um procedimento andarilho do olhar, um procedimento sensível, que requer o toque; é enxergar com os pés, palmilhando bordas cortantes, escarpas traiçoeiras e praias calmas que se estendem até muito longe.

Com efeito, a idéia de um campo autônomo para os estudos da comunicação e para a crítica das práticas da comunicação é já compartilhada, segundo paradigmas distintos, por várias das correntes. Há, entre nós, da Escola de Comunicações e Artes da Universidade de São Paulo, pelo menos três serspectivas diferentes em que a independência vem sendo áfirmada. Faço menção a elas por ter idọ buscar, em cada uma, referências para o que posteriormente eu deveria formular. Aqui, elas não aparecem em ordem de importância ou de grau de influência. Aparecem simplesmente como esforços diferenciados entre si que, no entanto, guardam um esforço comum: a busca da autonomia do campo.

Uma délas é representada, entre nós, por Maria Aparecida Baccega (Baccega, 1995, pp. 51-61). Seguidora da escola designada

3. A analogia com os paradigmas da Física não é estranhà à noção que Bourdieu (1996, p. 24) constrói de campo. É interessante notar essa proximidade em inúmeras passagens, quando ele invoca alguins conceitos newtonianos para falar em campo de forças e de forças gravitacionais a propósito do campo do poder e do campo da: literatura. O campo, nessa perspectiva, é entendido como um "sistema gravitacional" "autônomo, que age sobre qualquer corpo que se acerque de sua órbita próprià e que. gera códigos próprios de valores, gramáticas próprias e hierarquias éticas e estéticas que só nele, e dentro dele, fazem sentido. Ver, por exemplo: "Cada campo (religioso, artístico, cientifico, económico etc), através da forma particular de regulaçấo das: práticas e das representaçōes que impõe, oferece aos agentes uma forma legítima de realização de seus desejos, baseada em uma forma particular de illusio". (Bourdieu, 1996, p.259). 
Análise do Discurso, em que a noção de campo de Bourdieu tem um peso central, Baccega vislumbra e pleiteia um domínio autônomo para a comunicação dentro das 'ciências sociais. Nessa empreitada, ela preconiza a apropriação de conceitos' (pedras, fundamentais ou nem tanto) nascidos em outros campos ou domínios para cimentar as paredes de um novo edifício. É um projeto de risco, sem dúvida, mas inevitável. "No processo mesmo de incorporação, temos um primeiro momento da metassignificação, vez que essa ciência se desloca de seu domínio de origem ... e passa a fazer parte de um outro ", escreve a professora (Baccega, 1995, p. 56). A própria teoria do discurso assim vem se consolidando, a partir do diálogo com seus vizinhós próximos ou remotos. ${ }^{4} \mathrm{Em}$ Comunicação e linguagem: Discursos e Ciência (Baccega, 1998), Baccega aprofunda essa proposição, numa obra cujo "objetivo central" é "reinserir o estudo da comunicação no âmbito das ciências da linguagem enquanto parte das ciências sociais "(Martín-Barbero, 1998, p.3).

Ao falar em "âmbito das ciências da linguagem", Baccega dialoga, ainda que indiretamente, com uma outra perspectiva de emancipação do campo da comunicação, perspectiva essa também presente entre nós, sobretudo pelo trabalho de Jeanne Marie Machadó de Freitas. Radicalmente afastada dos paradigmas da Análise do Discurso, Jeanne Marie, autora de um trabalho seminal para os presentes estudos da comunicação, sustenta a autonomia das Ciências da Linguagem a partir de uma tradição que, nascida em Saussure, passa pela teoria psicanalítica de Jacques Lacan, constituindo então um domínio próprio. Mas agora já não se trata de um domínio em oposição a outros paralelos, mas de um domínio que englobará os outros - as Ciências da Linguagem passariam a conter boa parte das antigas Ciências Sociais. Seu Comunicação e Psicanálise é um marco teórico de alta relevância na produção acadêmica da ECA (Freitas, 1992). Sua obra abre perspectiva para que o sujeito do inconsciente entre na cena da comunicação - elemento que permitirá ver distâncias e profundezas que até então não podiam ser divisadas. É possível dizer,

4: Ver, por exemplo, Orlandi (1990, p. 26): “A teoria do discurso não pode, de forma alguma, substituir uma teoria da ideologia, não mais que uma teoria do inconsciente (embora suponha um sujeito afetado pela ideologia e pelo inconsciente), mas pode intervir no campo dessas teorias." 
sem risco de exagero, que os estudos que Jeanne Marie lidera na ECA têm um alcance que põe os estudos da linguagem num pólo de vanguarda das ciências sociais, tensionando-as num novo vórtice teórico. Para a autora, portantò, a autonomia está nas. Ciências da Linguagem - e não em um campo da comunicação do qual as ciências da linguagem fariam parte.

Por certo, a distinção entre uma linha (a da Análise do Discurso) e outra (as Ciências da Linguagem) é profunda e, conforme o plano em que se veja, inconciliável. Mas ambas podem ser vistas como expressão, ainda que em escalas próprias, distintas, de uma mesma vocação emancipatória para o campo que nos interessa.

Vale citar também uma terceira perspectiva, que comparece entre nós pelos trabalhos coordenados por Mauro Wilton de Sousa (Sousa, 1995). Para este pesquisador, os chamados estudos da recepção podem ser tomados como estudos da comunicação e, por aí, o campo da comunicação ensaia divisar sua especificidade frente às outras ciências sociais. Essa terceira perspectiva admite inúmeros interesses comuns com as outras duas. Por sinal, não seria incorreto pretender que, também pelas diferenças entre essas três perspectivas citadas, pelos próprios debates que passa a sediar, o campo da comunicação se converte num domínio com uma dinâmica científica interna cada vez mais intensa - e mais autônoma. Sua autonomia se manifestaria, dessa forma, não apenas naquilo que ela reivindica para si em relação às outras ciências sociais, mas principalmente em sua capacidade de expressar - e fazer dialogar entre si - suas correntes internas, que já são muitas. Um campo existiria assim menos por sua unicidade unívoca (um quase-pleonasmo) e mais pelas contradições intensas que conjuga - contradições que fazem dele uma coisa outra em relação às outras coisas.

$$
* \quad * \quad *
$$

Talvez por ter mergulhado nisso atravessando o vidro oblongo do monitor de TV (e ainda que exista a tela plana hodierna, o vídeo tem e terá sempre a forma histórica de um oblongo, que é o contorno dos campos de energia), eu enxergue o campo da comunicação como um campo que instaura espaços públicos ou que é por eles instaurado. Isso não engendra grandes mudanças em uma abordagem teórica, mas 
supõe a premissa de unituersós comuns - mais alargados ou mais reduzidos: Esses universós sã́o universos de sentido. Ao menos quando se pensa èm televiisãö; a premisissa é indiscutivel:

O que nos leva ä duas dás contigüidades definidoras (há outras, mas dessas outras não sé tratárá no presente artigo). Pois'bem; a comunicação posta pela televisão engendra espaços públicos. Aí, o campo da comunicação, agora considerado em sua dimensão de campo do conhecimento, faz a fronteira com a sociologia e, sobretudo, com a sociologia jurídica de Habermas. Ocorre que a comunicação posta pela televisão funciona menos como transmissão de mensagens controláveis por sistemas de gerenciamento e mais como linguagem, de tal sorte que o sujeito que aí se comunica não é propriamente o sujeito mais ou menos racional que transita nas pesquisas sociológicas em torno do espaço público, mas o "sujeito do inconsciente", para adotarmos aqui a expressão de Lacan tal como ela nos é legada pelos estudos de Janne Marie, ou seja, um sujeito submetido a outra ordem que não a da sua consciência individual. Assim, tateando e tateando, deslocamo-nos de uma fronteira com a sociologia para uma fronteira com a teoria psicanalítica.

A essas duas fronteiras se justapõem algumas outras, como a da lingüística e a do materialismo histórico, mas essas outras, como já está dito, não precisam ser mencionadas agora. A questão já é bastante controversa apenas com essas duas fronteiras porque: 1) para a sociologia habermasiana não existe o sujeito (do) inconsciente e 2) para a teoria psicanalítica as estruturas do espaço público fundado em premissas racionais resultam como conceitos meramente imaginários. E isso é apenas um dos muitos problemas duplos, tendo em vista apenas duas das fronteiras. O desafio que hoje incomoda o campo da comunicação é justamente esse, o de tornar viável o diálogo entre teorias assim incompatíveis. A existência de fronteiras simultâneas com teorias tão desconectadas nada mais é que a expressão de contradições internas quie, em lugar de negar, reafirmam a existência do campo tal como ele é aqui pretendido. São contradições internas constitutivas, essenciais, fundantes, do que quer que se entenda como campo da comunicação. Essa autonomia se afirma não apesar das incompatibilidades entre as ciências das quais ela é vizinha tão próxima, mas por causa dessas incompatibilidades. Elas, as ciências vizinhas, são incompatíveis entre 
si porque seìs objetos são estranhos entre si. ${ }^{5}$ Os objètos do campo da comunicação, no entanto, promovem-lhe novas compatibilidades, que sëriam impensáveis em seus respectivos campos de origem.

Ora, o que define um campo é seu objeto, seu método e seú discurso (níveis entrelaçados e inseparáveis) e só o campo da comunicação pode tomar por objeto a comunicação, cuja especificidade é inalcançável às outras ciências sociais. Delimitá-lo, lá vamos nós de novo nos socorrer do sensívél, requer o procedimento de olhar andarilho, que tateia os limites, de fora para dentro. E aqui já não nos serviria mais uma metáfora de inspiração gèográfica - porqủe o objeto nãó está lá, como um território estaria, antes que o discurso o constitua. Por isso discurso, métódo e objetó sã̃o inseparáveis. O campo começa onde uma fronteira - do discurso que lhe estranha - indica incompatibilidades insuperáveis. Ele existe onde sua existência é negada pelos discursós que lhe são exteriores. Ele existe onde gera o discurso próprio. $O$ discurso tece seu suporte.

Donde vale a pena insistir um pouco mais na idéià de espaço público - e nâs suas relações com a razão e com o inconsciente. Vale a pena repor, sempre; a mesma pérgunta: a comunicação pode ${ }^{t}$ ser concebida como a atividade fundadóra de espaço público? Indo ádiante: a comunicação que, na sociologia, é absorvida marginalmente como uma ferramenta para o atingimento de fins - e é na sociologia que vamos buscar as noçõès de esfera pública e espaço público $\rightarrow$, pode adquirir domínio sobre o espaço públičo? Piór ainda: pode-se, de volta ao campo da comunicação; virar a sociologia de ponta-cabeça?; pode-se, em vez de dizer que a comunicação é uma atividade que ocorre dentro do espaço público, dizer que o espaço público é que existe a partir da própria comunicação?

Perguntăs dessa ordem trazem, é claro, novas dúvidas. Uma deśsas, das mais incômodas, quẻestiona a idéia de consciência e a de racionalidade - pressupostos corriqueiros (ainda que centrais) na sociologia habermasiana màs, cada vez mais, anacrônicos na comunicação. Enquanto na sociologia a interação se faz com atores, falantes, agenteș que reúnem capacidades, "ainda que apenas

5. Já há estudos na USP que se ocuparam das relações possiveis entre Lacan e - Habermas, como o de Prado (1996). 
potencialmente, de exercer controle racional sobre os conteúdos de suas comunicações, nos estudos da comunicação a idéia desse domínio se revela cada vez mais uma ịdealização. Então: a racionalidade é mesmo uma premissa válida para a comunicação?

A resposta é desanimadora para a racionalidade. Esta, a racionalidade, vai se revelando não a solução, mas um grave problema no conceito habermasiano de espaço público (aos olhos que tenham seu ponto de vista alicerçados no turbulento campo da comunicação). No paradigma de Habermas, o inconsciẹte não tem lugar - a não ser como desvio ou como manipulação, que, em seu entender, é uma forma de fraudar a comunicação. Ora, para quem pense a partir do campo da comunicação, a manipulação, aquela mal-intencionada, existe, sem dúvida, mas está longe de ser um problema teórico. Deveria ser assunto de delegacia, não mais que isso. Deveria apenas ser condenada como desvio ético. Não mais que isso. Ela é origem de inúmeros problemas da democracia no espaço público, por certo, mas não é propriamente um mistério teórico para os estudos da comunicação: ela é apenas parte natural dessa comụnicação, cuja totalidade não se lhe põe como conseqüência, mas como determinação. Não é a manipulação que define como se dará a comunịcação e o que será tematizado pela comunicação: ao contrário, é o inconsciente na comunicação que suscita o expediente da manipulação nesșe ou naquele setor, com esse ou aquele grau de sucesso. A ordem de perguntas a se fazer aqui é, por exemplo: como age aí o inconsciente (lembrando, sempre, que nosso objeto, na comunicação, jamais será o inconsciente, que é objetọ da teoria psicanalítica, mas que nosso objeto na comunicação sofre a ação do inconsciente)?. Ou seja: como se insurge o inconsciente apesar dos monopólios, das estruturas de poder, de toda a manipulação e de todo o peso das racionalidades sistêmicas (usando aqui um termo familiar a Habermas)? De que modo a manipulação pode deixar de ser vista como uma iniciativa voluntária dos mecanismos de colonização do mundo da vida (Habermas, de novo) e pode ser vista como sintoma de uma estrutura que lhe é anterior - como. a linguagem na qual se inscreve? O conceito de manipulação perde, assim, boa parte de seu fascínio intelectual. Não por que não seja um problema prático (ele é um problema prático e político na sociedade contemporânea), mas por não encarnar um enigma teórico. Ela redunda num horizonte insosso, 
nada estimulante: é apenas uma manobra que pressupõe um certo grau de cálculo teleológico num sujeito relativamente desonesto em relação a seus interlocutores - de novo, a questão aqui é de delegacia de polícia. De resto, a existência desse sujeito tão solerte e tão superior é mais uma construção imaginária do que propriamente umạ categoria teórica aceitável na comünicação - e, embora não represente nenhum vício de método para a sociologia (e sobre a sociologia não estamos autorizados a emitir julgamentos), reduz as teorias da comuniçação à dinâmica de um jogo de pôquer. A pressuposição do sujeito superconsciente, enfim, se nãó desmonta a sociologia ou, ao menos a sociologia de corte mais habermasiano, é, sim, ư bloqueio para o avanço dós estúdos da comunicaçã̃o. Enquanto o tomar de modo acrítico, os estudos dä comunicação serão na melhor das hipóteses um campus avançado da sociologia ou da ciência política. Para a sociologia, a comunicação é uma ferramenta exterior - para a comunicação, a tal "ferramenta" da sociologia é o universo inteiro, tanto que a própria noção precária da comunicação como um meio que tem fins em vista se torna impossível.

, Uma nova interrogação: como os estudos da comunicação emancipados podem falar em espaço público se não admitem o sujeito teleológico que há no espaço público da sociologia e se são obrigados a lidar com vetores inconscientes e se esses vetores não fazem parte dos processos de formação da vontade e de opinião que caracterizam o espaço público? De outro lado: como os estudos da comunicaçấo podem falar em inconsciente se não têm autorização para ouvir os diálogos entre o psicanalista e aquele a cuja fala ele escuta?

Fiquem as perguntas èm aberto.

$* * * *$

Voltemos um pouco à televisão. O que a distingue frente aos outros eletrôdomésticos é á possibilidade históricá que ela abre para o que venho chamando de instância da imagem ao vivo. Com o advento dos meíos de comunicação de massa, no dizer de Habermas̆, a esfera pública se expandiu. Depois disso, a instância da imạgem ao vivo é o que modificou por inteiro as maneiras de se conceber socialmente a espacialidadé e a temporalidade. Ela não é um meio nèm um veículo, mas um padrão que passa a ditar espacialidade e temporalidade na comunicação, passa a ditar o alargamento da esfera pública. Podemos 
dizer que ela não é um "meio" ou um "veículo" pelo simples fato de que não transporta conteúdos prontos de um pólo (emissor) a outro (réceptor), mas age na constituição dos vínculos, digamos, comunicativos - que não são outros senão os vínculos sociais traduzidos èm linguagem. Isso, a meu ver, vale também para os estudos da comunicaçã̀o que não tenham a TV como seu objeto primeiro.

A internet, por exemplo. Ela não revoga a instância dá imagem ao vivo. Ao contrário, só faz aprofundá-la, pois só faz encurtar ainda mais as distâncias e abreviar os prazos, tendência imperiosa que foi posta pela expansão da esfera pública acrescida da instância da imagem aò vivo. E esśa tendência imperiosa se devé tanto às exigências do cäpital (que requer a ubiqüidade $\mathrm{e} a$ instantaneidade) quanto às exigências do espetáculo (que requer as mesmas ubiqüidade e instantaneidade pois ele, o espetáculo, é "o capital em tal grau de acumulação que se torna imagem" [Debord, 1997, p. 25]). A Internet não revoga essa tendência; radicaliza-a. É verdade que a televisão, assim como os bancos de dados ou as revendedoras de automóveis, pode sim se fundir à internet. Naturalmente, é possível ver TV pela Internet, como já é possível fazer compras de supermercado pelo cómputador (logo mais, a geladeira estará conectada à internet para que emita automaticamente pedidos de compra ao empório virtual mais próximo à medida que o estoque doméstico vá minguando). Tudo isso, porém, não significa que a televisão tenha sido sepultada: a instância da imagem ao vivo não o foi; tornou-se ainda mais dominante. A internet, importa registrar, como tela eletrônica e como "interatividade" (essa palavra estranha que apenas se grafa neste artigo por motivos de condescendência semântica), prossegue, com o computador, uma obra iniciada pelo aparelho conhecido como televisão.

Como exemplo do que pode ser um objeto pertencente e pertinente ao campo da comunicação, podemos definir provisoriamente a televisão como o nexò simultaneamente tecnológico e social que instaura a comunicaçã̃o pela instância da imagem ao vivo como padrão de temporalidade (instantaneidade) e de espacialidade (ubiqüidade) no espaço público. É, pois, indiferente se essa comunicação ocorre por internet, por antena convencional, por antena parabólica, por fibra ótica ou, ainda, por um sistema que combine tudo isso. Não importa se essa televisão é mais ou menos "interativa". Importa apenas o caráter 
de nexo (vínculo) a um tempo e indissociavelmente tecnológico e social entre sujeitos de quaisquer dimensões instaurando a comunicação pela instância da imagem ao vivo: Aqui resvalamos numa sutileza decisiva: por instância da imagem ao vivo não se entende estritamente o.advento das ditas transmissões ao vivo. Entende-se a condição imediata e permanente de estar ao vivo a qualquer instante, porque se está online o tempo todo, em todos os 'espaços. O online é, portanto, parte da instância da imagem ao vivo que prolonga a instância da imagem ao vivo. A televisão como objeto é, por definição, o nexo que instaura um campo social de comunicação diferenciada e, não obstante, hegemônica no espaço público. Recorro a essa definição, embora precárià e meramente inicial, porque penso que ela ajuda a entender um pouco mais o que proponho acerca do campo da comunicação.

$$
\text { *** }
$$

No território (geográfico?) independente que se encontra em formação para os estudos da comunicação, cada vez menos são determinantes as categorias de emissor e receptor - e isso vale mesmo para os chamados Estudos da Recepção, nos quais o receptor não é apenas "receptor", por não ser passivo, mas um sujeito autônomo na confecção do sentido. Cada vez mais é preciso investigar - e aí a lingüística se converte numa fonte de elucidação - de que modo a linguagem não pertence nem ao emissor nem ao receptor, pois essa mesma chave serve para os estudos da comunicação. Essa investigação se justifica para que se possa, a partir dela, importar o conceito de espaço público para um campo novo, onde ele possa conviver com a emergência do inconsciente - ou do sujeito do inconsciente. Pois, como estamos vendo, o espaço público e se manifesta também como campo de práticas comunicativas onde o inconsciente cabe e onde $o$ inconsciente atua. Repita-se: o inconsciente não é o nosso objeto, mas se manifesta na comunicação. E modula essa comunicação.

Lembremo-nos de que, assim como a própria língua, que institui-se como laço social (comunicacional) sem subordinar-se a nenhum senhor que não seja o todo da comunidade falante, um todo cujo arco cronológico é muito mais extenso que a distância entre a vida e a morte de várias gerações e cujo arco espacial estende-se para 
além das distâncias físicas passíveis de ser percorridas por um indivíduo, a comunicação busca a produção da significação na intersubjetividade - e, a propósito, só depois, num plano incomparavelmente inferior; subordina-se às tentativas de manipulação.

E, afinal; a pergunta retorna: em que lugar está a comunicação? A pergunta retorna e prosseguirá, por algum tempo ainda. Nas diferenças é que talvez nos descubramos, logo adiante, como pertencentes a um solo teórico provavelmente comum.

\section{Bibliografia}

BACCEGA, M. A. 1995. “O campo da comunicação" In: CORRÊA, Tupã Gomes. Comunicação para o mercado. São Paulo: Edicon. 1998. Comunicação e linguagem: Discursos e ciência. São Paulo: Moderna.

BOURDIEU, Pierre. 1984. Questions de sociologie. Paris: Éditions de Minuit.

*.1990. Coisas ditas. São Paulo: Editora Brasiliense.

1996. As regras da arte: gênese e estrutura do campo literário. São Paulo: Companhia das Letras.

DEBORD, Guy. 1997. A sociedade do espetáculo. Rio de Janeiro: Contraponto.

FREITAS, Jeanne Marie Machado de. 1992. Comunicação e psicanálise. São Paulo: Escuta.

MARTÍN-BARBERO, Jesús. 1998. "Prefácio". In: BACCEGA, Maria Aparecida; Comunicação e linguagem: Discursos e ciência. São Paulo: Moderna.

ORLANDI, Eni. 1990. Terra à Vista. São Paulo: Cortez, p. 26.

PRADO, Luiz Åidar do. 1996. Brecha na comunicação: Habermas, o outro, Lacan. São Paulo: Hacker.

SOUSA, Mauro Wilton de. 1995. "Recepção e comunicação: a busca do sujeito". In:. SOUSA, Mauro Wilton de (org.) Sujeito, o lado oculto do receptor. São Paulo: Brasiliense. 